\title{
Actinomyces naeslundii
}

National Cancer Institute

\section{Source}

National Cancer Institute. Actinomyces naes/undii. NCI Thesaurus. Code C86110.

A species of anaerobic, Gram positive, rod shaped bacteria assigned to the phylum

Actinobacteria. This bacteria is urease positive, hydrolyzes esculin and does not produce acid from mannitol. A. naeslundii is a commensal organism of the oral cavity and colonizes tooth surfaces but may cause infection and periodontal disease in cases in which oral trauma occurs. 